\title{
In vitro Cytotoxic and Antimicrobial Activity of Essential Oil From Satureja Intermedia
}

\author{
Iman Sadeghi ${ }^{1}$, Morteza Yousefzadi ${ }^{2,},{ }^{*}$, Mehrdad Behmanesh ${ }^{1}$, Mozafar Sharifi ${ }^{3}$, Aiuob Mo- \\ radi $^{4}$ \\ ${ }^{1}$ Department of Genetics, Faculty of Biological Sciences, Tarbiat Modares University, Tehran, IR Iran, \\ ${ }^{2}$ Department of Biology, Faculty of Basic Sciences, Hormozgan University, Bandar Abbas, IR Iran, \\ ${ }^{3}$ Department of Plant Biology, Faculty of Biological Sciences, Tarbiat Modares University, Tehran, IR Iran, \\ ${ }^{4}$ Agricultural and Natural Resources Research Center, Gilan, IR Iran, \\ * Corresponding author:Morteza Yousefzadi, Corresponding author: Morteza Yousefzadi, Department of Biology, Faculty of Basic Sciences, Hormozgan \\ University, Bandar Abbas, IR Iran, Tel/Fax:+98-9121886139, Email:, E-mail: morteza110110@gmail.com.
}

\begin{abstract}
A B S T R A C T
Background: Many members of the genus Satureja have aromatic and medicinal characteristics.

Objectives: The purpose of the present work was to determine cytotoxic activity of the essential oil of S. intermedia CA Mey(Lamiaceae) on two human cancerous cell lines and its in vitro inhibitory effects against 11 pathogenic bacteria and fungi as well.

Materials and Methods: The essential oil was isolated by hydrodistillation and analyzed by combination of capillary GC-FID and GC-MS. The in vitro toxicological study was based on the MTT cytotoxicity assay and antimicrobial activity of the essential oil was studied according to the disc diffusion method and MIC value.

Results: Thymol (34.5\%), $\gamma$-terpinene (18.2\%) and $\rho$-cymene (10.5\%) were the main components of the essential oil. The toxicological study on 5637 and KYSE cell lines showed IC50 values of $156 \mu \mathrm{g} / \mathrm{ml}$. The essential oil exhibited considerable antimicrobial activity on tested bacteria and fungi.

Conclusions: From the results of the present study, it may be concluded that the essential oil of S. intermedia and its major constitutes are interesting in antibacterial and anticancer applications.

Keywords: Satureja; Gas Chromatography-Mass Spectrometry; Thymol
\end{abstract}

\section{Background}

Essential oils are complex mixtures of odorous and volatile compounds obtained from many plants and have recently gained popularity and scientific interest. Aromatic plants have long been used for spices and natural food conservancies, in the perfume industry and aromatherapy and for different medical purposes. Researchers have been interested in biologically active compounds isolated from plant species for the elimination of pathogenic microorganisms because of the resistance that microorganisms have built against current antibiotics. Also some essential oils were shown to elicit cytotoxicity and induce apoptosis on the cancerous cells. Based on cytotoxicity bioassay, over 400 compounds have been isolated from plants $(1,2)$.

The genus Satureja L. (Lamiaceae) comprises more than 200 species of aromatic herbs and shrubs, mainly distributed in the Mediterranean region. This genus is represented by 14 species from which 8 species are endemic and are distributed commonly in mountainous regions of Iran

Article type: Research Article; Received: 27 Mar 2012, Revised: 19 Jun 2012, Accepted: 15 Jul 2012; DOI: 10.5812/ircmj.4989

Implication for health policy/practice/research/medical education:

The purpose of the present study was to determine cytotoxic activity of the essential oil of S. intermedia CA Mey(Lamiaceae) on two human cancerous cell.

Please cite this paper as:

Sadeghi I, Yousefzadi M, Behmanesh M, Sharifi M, Moradi A. In vitro Cytotoxic and Antimicrobial Activity of Essential Oil From Satureja Intermedia. Iran Red Cres Med J. 2013;15(1):70-4. DOI: 10.5812/ircmj.4989

Copyright @ 2013, Iranian Red Crescent Medical Journal; Published by Kowsar Corp.

This is an Open Access article distributed under the terms of the Creative Commons Attribution License (http://creativecommons.org/licenses/by/3.0), which permits unrestricted use, distribution, and reproduction in any medium, provided the original work is properly cited. 
(3-5). Many members of the genus Satureja have aromatic and medicinal properties. The essential oil compositions and antimicrobial activities of some Satureja species have been studied (6-9). These studies have revealed that the Satureja species have antimicrobial activity against human, food, and plant pathogens due to the presence of phenolic components such as thymol and carvacrol $(10,11)$.

Earlier studies revealed that the essential oil of Satureja species are rich in carvacrol, $\gamma$-terpinene, thymol, and pcymene $(12,13)$. However the percentage or presence of some main components in the essential oils of this genus shows a noticeable diversity $(14,15)$. Although antimicrobial activity of the essential oil of some Satureja species has been previously reported, $(6,7,10,16)$ antimicrobial and cytotoxic activity of S. intermedia essential oil have not been studied so far.

\section{Objectives}

In this study, we reported the results of cytotoxic activity of the essential oil of S. intermedia and evaluation of its in vitro inhibitory effects against 8 pathogenic Grampositive and Gram-negative bacteria in addition to three pathogenic fungi as well.

\section{Materials and Methods}

\subsection{Plant Material}

The aerial parts of S. intermedia were collected, on June 2009 at full flowering stage from Talesh, Iran, at an altitude of $1750 \mathrm{~m}$. The plant material was identified by Dr. Hadian and a voucher specimen (HAPH-88121) is deposited at the Herbarium of Biology Department, Hormozgan University, Bandar Abbas, Hormozgan Province, Iran.

\subsection{Essential Oil Isolation}

The powdered plant aerial parts (250 g) were hydrodistilled using a Clevenger type apparatus for 3 hours according to the method recommended in British Pharmacopoeia. The resulting essential oil was dried over anhydrous sodium sulfate and stored at $4^{\circ} \mathrm{C}$ until analyzed and tested.

\subsection{Essential Oil Analysis and Identification Proce- dure}

GC-FID analyses of the oil were conducted using a Thermoquest-Finnigan instrument equipped with a DB-5 fused silica column $(60 \mathrm{~m} \times 0.25 \mathrm{~mm}$ i.d., film thickness $0.25 \mu \mathrm{m})$. Nitrogen was used as the carrier gas at the constant flow of $1.1 \mathrm{ml} / \mathrm{min}$. The split ratio was $1 / 50$. The oven temperature was raised from $60^{\circ} \mathrm{C}$ to $250^{\circ} \mathrm{C}$ at a rate of $5{ }^{\circ} \mathrm{C} / \mathrm{min}$. The injector and detector (FID) temperatures were kept at $250^{\circ} \mathrm{C}$ and $280^{\circ} \mathrm{C}$, respectively. GC-MS analy- sis was carried out on a Thermoquest-Finnigan Trace GC-MS instrument equipped with the same column and temperature programming as mentioned for GC. Transfer line temperature was $250^{\circ} \mathrm{C}$. Helium was used as the carrier gas at a flow rate of $1.1 \mathrm{ml} / \mathrm{min}$ with a split ratio equal to $1 / 50$.

The constituents of the essential oils were identified by calculation of their retention indices under temperatureprogrammed conditions for n-alkanes (C6-C24) and the oil on a DB-5 column under the same conditions. Individual compounds were identified by comparison of their mass spectra with those of the internal reference mass spectra library (Wiley 7.0) or with authentic compounds and confirmed by comparison of their retention indices with authentic compounds or with those of reported in the literature (17). Semi-quantitative data was obtained from FID area percentages without the use of correction factors.

\subsection{Microbial Strains}

Eleven microbial strains were used in the antimicrobial activity assay, which included; Bacillus subtilis (ATCC 465), B. pumulis (PTCC 1274), Enterococcus faecalis (ATCC 29737), Staphylococcus aureus (ATCC 25923), Staphylococcus epidermidis (ATCC 12228), Escherichia coli (ATCC 25922), Klebsiella pneumoniae (ATCC 10031), Pseudomonas aeruginosa (ATCC 85327), Aspergillus

niger (ATCC 16404), Candida albicans (ATCC 10231) and Saccharomyces cerevisiae (ATCC 9763).

\subsection{Antimicrobial Screening}

The antimicrobial activity of the essential oil and its main component was determined by the disk diffusion method (18). Briefly, $0.1 \mathrm{ml}$ of a suspension of the test microorganism $\left(10^{8}\right.$ cells $\left./ \mathrm{ml}\right)$ was spread on Mueller-Hinton Agar plates for bacteria and Sabouraud Dextrose Agar for the fungi. Sterile $6 \mathrm{~mm}$ disks, containing $10 \mu \mathrm{l}$ of essential oil were placed on the microbial lawns. The plates were incubated at $37^{\circ} \mathrm{C}$ for 24 hours for bacteria and $30^{\circ} \mathrm{C}$ for 48 hours for fungi. The diameters of the zones of inhibition were measured and reported in $\mathrm{mm}$. Triplicate tests were carried out in all experiments.

\subsection{Determination of Minimum Inhibitory Con- centration (MIC)}

MIC values were determined by broth microdilution assay recommended by the NCCLS (19). Serial two-fold dilutions of the essential oil were made in Mueller-Hinton Broth containing 0.5\% Tween 80 for bacteria and Sabouraud Dextrose Broth with $0.5 \%$ Tween 80 for fungi in 96-well micro titer plates. Fresh microbial suspensions prepared from overnight grown cultures in the same media were added to give a final concentration of $5 \times 105$ or- 
ganisms $/ \mathrm{ml}$. Controls of medium with microorganisms or the essential oil were included. The microplates were incubated at $37^{\circ} \mathrm{C}$ for 24 hours for bacteria and $30^{\circ} \mathrm{C}$ for 48 hours for fungi. The first dilution with no microbial growth was recorded as MIC.

\subsection{Cell line and Culture}

The human oesophagus squamous cell carcinoma (KYSE30) and human bladder carcinoma cell line (5637) were obtained from Pasteur Institute of Iran. Cells were cultured in RPMI-1640 supplemented with 10\% fetal bovine serum (Gibco) and $1 \%$ penicillin-streptomycin, at $37^{\circ} \mathrm{C}$, in humidified air containing $5 \% \mathrm{CO} 2$.

\subsection{Cytotoxicity Assay}

Cytotoxicity was assessed by the tetrazolium-based colorimetric assay (MTT) which measures the reduction of the tetrazolium salt MTT (3-[4,5-dimethylthiazol-2-yl]-2, 5-diphenyltetrazolium bromide; Roche) into a blue formazan product, mainly by the activity of the mitochondrial enzymes, cytochrome oxidase and succinate dehydrogenase. Typically, $100 \mu \mathrm{l}$ of cells suspension were plated at a density of approximate $2 \times 10^{4}$ cells per well in a 96-well plate, and were subsequently incubated at $37^{\circ} \mathrm{C}$ in a 5\% CO2 humid incubator for 24 hours. Then essential oils with different concentrations were added to each group (triplicate wells) and the incubation was continued for $24 \mathrm{~h}$, followed by adding $10 \mu \mathrm{l}(5 \mathrm{mg} / \mathrm{ml})$ of MTT dye solution to each well for 4 hours at $37^{\circ} \mathrm{C}$. After removal of the MTT dye solution, cells were treated with $100 \mu \mathrm{LMSO}$ and the absorbance at $490 \mathrm{~nm}$ was quantified using ELISA reader. The cytotoxicity was calculated after comparing with the control (treated with 0.1\% DMSO). Cytotoxicity is expressed as the concentration of drug inhibiting cell growth by 50\% (IC50). All tests and analysis were run in triplicate and mean values recorded.

\section{Results}

\subsection{Chemical Composition of Essential Oil}

The essential oil was obtained by hydrodistillation from the aerial part of S. intermedia and then subjected to GC and GC/MS to identify its composition. Qualitative and quantitative analytical results are shown in Table 1 in which compounds are listed in order of their elution on the DB- 5 column. The yield of essential oil was $0.52 \%$ (w/w) on dry weight basis. In our study, thymol (34.5\%), $\gamma$-terpinene (18.2\%), $\rho$-cymene (10.5\%), limonene (7.3\%), $\alpha$-terpinene (7.1\%), carvacrol (6.9\%) and elemicine (5.3\%) were the main compounds. In another research on $S$. intermedia, thymol (32.3\%), $\gamma$-terpinene (29.3\%) reported as the main compounds.15. The contents of carvacrol, p- cymene and specially thymol are usually present as major compounds in the oil of other Satureja species (20-22). These differences may be due to several reasons: genetic diversity, climatic conditions, ecological differences (23).

\begin{tabular}{lll}
\hline \multicolumn{2}{l}{ Table 1. Main Components of the Essential Oil of S. intermedi } \\
\hline Compound & Retention index & Percentage \\
\hline Thymol & 1290 & 34.5 \\
$\gamma$-Terpinene & 1062 & 18.2 \\
P-Cymene & 1024 & 10.5 \\
Limonene & 1031 & 7.3 \\
\hline $\boldsymbol{\alpha}$-Terpinene & 1018 & 7.1 \\
\hline Carvacrol & 1297 & 6.9 \\
\hline Elemicine & 1554 & 5.3 \\
\hline
\end{tabular}

\subsection{Antimicrobial Activity}

Inhibition zones (IZ) and minimum inhibitory concentration (MIC) values of the essential oil, its major compound and standard antibiotic are shown in Table 2 . The results of the antimicrobial activities of the essential oil indicated that the oil exhibited moderate to high antimicrobial activity. According to these results, essential oil of this species exhibited considerable antimicrobial activity on tested bacteria and fungi except for two resistant microbial strains: A. niger (fungus) and P. aeruginosa (Gram-negative bacteria). The data showed that B. pumulis, B. subtilis and S. epidermidis were the most sensitive microorganisms to the oil with the inhibition zones 36 , 35 and $33 \mathrm{~mm}$ and MIC values of $0.465,0.465$ and 0.93 $\mathrm{mg} / \mathrm{ml}$, respectively. Among bacteria P. aeruginosa, E. faecalis and K. pneumonia were the most resistant bacteria against the essential oil.

Analysis of antimicrobial activity of the essential oil on fungi also revealed that A. niger is absolutely insensitive to essential oil however S. cervisiae showed to be the most sensitive fungus against essential oil with IZ and MIC values as $15 \mathrm{~mm}$ and $3.75 \mathrm{mg} / \mathrm{ml}$, respectively. Although the essential oil of the present species showed both antifungal and antibacterial activity, but the IZ and MIC values for fungi were much higher than that of bacteria which shows the higher antibacterial potent of the essential oil comparing to antifungal activity. By comparing the antimicrobial activity of the essential oil of S. intermedia in this study with its composition, it can be suggested that thymol which is the major components of the essential oil of this plant might be responsible compounds for antimicrobial activity of this species. Antimicrobial activity of thymol is considered as a major component of the oil tested. The result showed that thymol exhibit antibacterial activity is stronger than antifungal activity (Table 2). 
Table 2. Antimicrobial Activity of Essential Oils From S. intermedia

\begin{tabular}{|c|c|c|c|c|c|c|}
\hline \multirow{2}{*}{$\begin{array}{l}\text { Microorgan- } \\
\text { isms }^{\text {a }}\end{array}$} & \multicolumn{2}{|c|}{ S. intermedia } & \multicolumn{2}{|l|}{ Thymol } & \multicolumn{2}{|c|}{ Standard antibiotics } \\
\hline & $\mathbf{I Z}^{\mathrm{b}}$ & $\mathrm{MIC}^{\mathrm{C}}$ & IZ & MIC & Ampicillin $^{\mathrm{d}}$ & Nystatine $^{\mathrm{e}}$ \\
\hline B. subtilis & $35 \pm 0.3$ & 0.465 & $46 \pm 0.5$ & 0.23 & $14 \pm 0.4$ & - \\
\hline B. pumulis & $36 \pm 0.2$ & 0.465 & $47 \pm 0.3$ & 0.23 & $15 \pm 0.3$ & - \\
\hline E. faecalis & $12 \pm 0.2$ & 7.5 & $25 \pm 0.2$ & 1.75 & $11 \pm 0.3$ & - \\
\hline S. aureus & $20 \pm 0.3$ & 3.75 & $34 \pm 0.2$ & 0.465 & $13 \pm 0.3$ & - \\
\hline S. epidermidis & $33 \pm 0.5$ & 0.93 & $38 \pm 0.4$ & 0.465 & $19 \pm 0.5$ & - \\
\hline E. coli & $12 \pm 0.3$ & 7.5 & $32 \pm 0.5$ & 0.465 & $12 \pm 0.2$ & - \\
\hline K. pneumoniae & $11 \pm 0.4$ & 7.5 & $24 \pm 0.6$ & 1.75 & - & - \\
\hline P. aeruginosa & 0 & - & $12 \pm 0.2$ & 7.5 & $10 \pm 0.3$ & - \\
\hline A. niger & 0 & - & 10 & 7.5 & - & $16 \pm 0.4$ \\
\hline C.albicans & $13 \pm 0.5$ & 7.5 & 14 & 3.75 & - & $18 \pm 0.5$ \\
\hline S. cerevisiae & $15 \pm 0.7$ & 3.75 & 18 & 1.75 & - & $18 \pm 0.2$ \\
\hline \multicolumn{7}{|c|}{$\begin{array}{l}\text { a Inactive (-); moderately active ( } 7 \text { - } 14) \text {; highly active }(>14 \\
\text { b Inhibition Zone includes diameter of disc }(6 \mathrm{~mm}) \\
{ }^{c} \text { Minimum inhibitory concentration values as } \mathrm{mg} / \mathrm{ml} \\
\mathrm{d}_{\text {Tested at } 10 \mu \mathrm{g} / \text { disc }} \\
\mathrm{e}_{\text {Tested at } 30 \mu \mathrm{g} / \text { disc }}\end{array}$} \\
\hline
\end{tabular}

\section{Discussion}

Antimicrobial activity of other Satureja species on our tested bacteria or fungi or other types of microorganisms have been previously studied. Sonboli et al. (22), reported that the antimicrobial activity of essential oil of $S$. laxiflora which thymol was the main component of the essential oil proposed to be responsible for its antimicrobial activity. The effect of S. montana and S. subspicata oils were also reported and essential oils extracted from $S$. spicigera, S. biflora, S. masukensis and S. pseudosimensis showed a high inhibition against a wide range of microorganisms $(7,16,24)$. It has been proposed that the essential oils which are rich in phenolic compounds may exert a high antimicrobial activity (25).

To evaluate the effect of essential oils on cell viability, cytotoxicity assay was performed, increasing drug concentrations and the cell viability were determined by the MTT assay. For these assays, cultured cells were exposed to essential oil for 24hours. The results of cytotoxicity of the essential oil of S. intermedia on the human bladder carcinoma cell line (5637) and human oesopphagus squamous cell carcinoma (KYSE30) cell lines after 24hours exposure at dosages ranging from 39 to $1000 \mu \mathrm{g} / \mathrm{ml}$ were shown in Figure 1. Essential oil significantly reduced cell viability of KYSE30 and 5637 cells in a dose-dependent manner starting 39 to $1000 \mu \mathrm{g} / \mathrm{ml}$ with IC50 $156 \mu \mathrm{g} / \mathrm{ml}$.

Cytotoxicity of thyme essential oil was investigated on the HNSCC and UMSCC cell lines. Essential oils and their individual volatile components have been brought the attention of research groups on cancer (26). A number of articles are devoted to investigate their effect against a variety of human cancer cell lines.

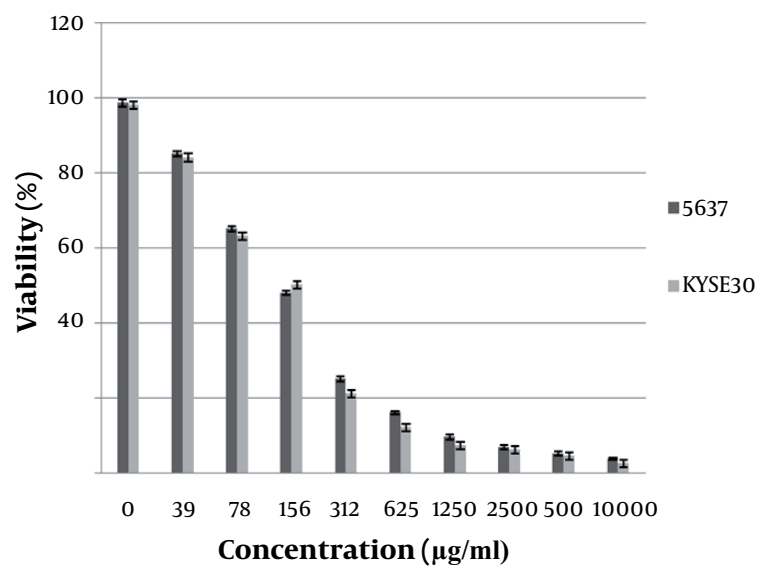

Figure 1. Cytotoxicity of the Essential Oil From S. intermedia. Viability Values Were Expressed as the Mean \pm S.D., Determined From the Results of MTT Assay in Triplicate Experiments

Numerous reports showed the high cytotoxic properties of terpenes, and phenolics against cancer cell lines (27). The IC50 of thyme essential oil extract was $369 \mu \mathrm{g} / \mathrm{ml}(28)$. In another study, the genotoxic effects of thymol were investigated in human peripheral lymphocytes treated with $25,50,75$, and $100 \mu \mathrm{g} / \mathrm{ml}$ concentrations. Thymol induced structural chromosome aberration and frequency of micronucleus at all concentrations (29).

Our result in this study represented that the essential oil of S. intermedia like other mentioned Satureja species in this paper has a great potent for antimicrobial properties in addition to cytotoxic activities. These data indicate the possibility that $S$. intermedia oil and its constituents may be applied as an antibacterial agent and moreover 
an anticancer agent.

\section{Acknowledgements}

None declared.

\section{References}

1. Kim J, Park EJ. Cytotoxic anticancer candidates from natural resources. Curr Med Chem Anticancer Agents. 2002;2(4):485-537.

2. Tepe B, Daferera D, Sokmen A, Sokmen M, Polissiou M. Antimicrobial and antioxidant activities of the essential oil and various extracts of Salvia tomentosa Miller (Lamiaceae). Food Chem. 2005;90(3):333-340.

3. Rechinger KH. Satureja. In: Cavaleiro C, Salgueiro LR, Antunes T, editors. Flora Iranica. Graz, Austria: Sevinate; 1980.

4. Jamzad Z. Satureja rechingeri (Labiatae): a new Stream. Species from Iran. Ann Naturhist Mus Wien.1996;98(B Suppl):75-77.

5. Mozaffarian V. A Dictionary of Iranian plant names. Tehran, Iran: Farhang Moaser; 1996.

6. Ciani M, Menghini L, Mariani F, Pagiotti R, Menghini A, Fatichent F. Antimicrobial properties of essential oil of Satureja montana L on pathogenic and spoilage yeasts. Biotech Lett. 2000;22(12):1007 1010.

7. Eftekhar F, Raei F, Yousefzadi M, Ebrahimi SN, Hadian J. Antibacterial activity and essential oil composition of Satureja spicigera from Iran. Z Naturforsch C. 2009;64(1-2):20-24.

8. Goren AC, Topcu G, Bilsel G, Bilsel M, Wilkinson JM, Cavanagh H. Analysis of essential oil of Satureja thymbra by hydrodistillation, thermal desorber, and headspace GC/MS techniques and its antimicrobial activity. Nat Prod Res. 2004;18(2):189-195.

9. Tzakou O, Skaltsa H. Composition and antibacterial activity of the essential oil of Satureja parnassica subsp parnassica. Planta Med. 2003;69(3):282-284

10. Adiguzel A, Ozer H, KiliC H, CetiN B. Screening of antimicrobial activity of essential oil and methanol extract of Satureja hortensis on foodborne bacteria and fungi. Czech J Food Sci.2007;25(2):81.

11. Gulluce M, Sokmen M, Daferera D, Agar G, Ozkan H, Kartal N, et al. In vitro antibacterial, antifungal, and antioxidant activities of the essential oil and methanol extracts of herbal parts and callus cultures of Satureja hortensis L. J Agric Food Chem. 2003;51(14):39583965.

12. Ghannadi A. Composition of the essential oil of Satureja hortensis L. seeds from Iran. J Essent Oil Res. 2002;14(1):35-36.

13. Kurkcuoglu M, Tumen G, Baser KHC. Essential oil constituents of Satureja boissieri from Turkey. Chem Nat Comp. 2001;37:329-31.

14. Hadian J, Ebrahimi SN, Salehi P. Variability of morphological and phytochemical characteristics among Satureja hortensis L. accessions of Iran. Ind Crop Prod. 2010;32(1):62-69.

15. Sefidkon F, Jamzad Z. Chemical composition of the essential oil of three Iranian Satureja species (S. mutica, S. macrantha and S intermedia). Food Chem. 2005;91(1):1-4.

16. Ćavar S, MaksimoviĆ M, ŠoliĆ ME, JerkoviĆ-MujkiĆ A, Bešta R Chemical composition and antioxidant and antimicrobial activ ity of two Satureja essential oils. Food Chem. 2008;111(3):648-653.

17. Adams R. Quadrupole mass spectra of compounds listed in order of their retention time on DB-5. Identification of essential oils components by gas chromatography/quadrupole mass spectroscopy. Allured Publishing Corporation, Carol. Stream, IL, USA; 2001

18. National Committee for Clinical Laboratory Standards, Watts JL Performance standards for antimicrobial disk susceptibility test (6th ed.). Approved Standard. M100-A6. Pensylvania, USA: Wayne; 1997.

19. Standards NCfCL. Performance standards for antimicrobial susceptibility testing. 9th International Supplement. M100-S9. Pensylvania, USA: Wayne; 1999.

20. Gohari AR, Hadjiakhoondi A, Shafiee A, Ebrahimi ES, Mozaffarian V. Chemical composition of the essential oils of Satureja atroplatana and Satureja mutica growing wild in Iran. J Essent Oil Res. 2005;17:17-18.

21. Sefidkon F, Ahmadi S. Essential oil of Satureja khuzistanica Jamzad.J Essent Oil Res. 2000;12(4):427-428.

22. Sonboli A, Fakhari A, Kanani MR, Yousefzadi M. Antimicrobial activity, essential oil composition and micromorphology of trichomes of Satureja laxiflora C. Koch from Iran. Z Naturforsch C. 2004;59(11-12):777-781.

23. Runyoro D, Ngassapa O, Vagionas K, Aligiannis N, Graikou K, Chinou I. Chemical composition and antimicrobial activity of the essential oils of four Ocimum species growing in Tanzania. Food Chem. 2010;119(1):311-316.

24. Vagionas K, Graikou K, Ngassapa O, Runyoro D, Chinou I. Composition and antimicrobial activity of the essential oils of three Satureja species growing in Tanzania. Food Chem. 2007;103(2):319-324.

25. Oke F, Aslim B, Ozturk S, Altundag S. Essential oil composition, antimicrobial and antioxidant activities of Satureja cuneifolia Ten. Food Chem. 2009;112(4):874-879.

26. Doll-Boscardin PM, Sartoratto A, Sales Maia BH, Padilha de Paula J, Nakashima T, Farago PV, et al. In Vitro Cytotoxic Potentia of Essential Oils of Eucalyptus benthamii and Its Related Terpenes on Tumor Cell Lines. Evid Based Complement Alternat Med. 2012;2012:342652.

27. Walia M, Mann TS, Kumar D, Agnihotri VK, Singh B. Chemical Composition and In Vitro Cytotoxic Activity of Essential Oil of Leaves of Malus domestica Growing in Western Himalaya (India).Evid Based Complement Alternat Med. 2012;2012:649727.

28. Sertel S, Eichhorn T, Plinkert PK, Efferth T. Cytotoxicity of Thymus vulgaris essential oil towards human oral cavity squamous cell carcinoma. Anticancer Res. 2011;31(1):81-87.

29. Buyukleyla M, Rencuzogullari E. The effects of thymol on sister chromatid exchange, chromosome aberration and micronucleus in human lymphocytes. Ecotoxicol Environ Saf. 2009;72(3):943-947. 